\title{
Field trials of low dose Bayluscide on snail hosts of schistosome and selected non-target organisms in sahelian Cameroon
}

\author{
I Takougang/*/+, J Meli*, F Angwafo III**
}

Department of Public Health **Department of Urology, Faculty of Medicine and Biomedical Sciences, University of Yaounde I, P.O. Box 1364 Yaounde 1, Cameroon *Foundation for Health Research \& Development, P.O. Box 8004 Yaoundé, Cameroon

More than $85 \%$ of all cases of schistosomiasis in Cameroon occur in the northern sahelian half of the country representing $20 \%$ of the population. Several workers have advocated the integrated approach to schistosomiasis control, including snail control, but the death and decay of aquatic organisms, and fish kill that often follows Bayluscide application at the dose of $1 \mathrm{~g} / \mathrm{m}^{3}$ decrease its acceptability. The present study was designed to assess the effect of lower Bayluscide doses on snail host and non-target fish, frog, the tadpole kill. Bayluscide was applied to study ponds at concentrations of $0,0.25,0.5$, and $1 \mathrm{~g} / \mathrm{m}^{3}(\mathrm{ppm})$. Pre and post application assessment of snails hosts of schistosomes, fish, frog, and tadpole kill were carried out. All 0.25, 0.5, and $1 \mathrm{~g} / \mathrm{m}^{3}$ Bayluscide concentrations reduced snail population significantly. Bayluscide concentration of $0.50 \mathrm{~g} / \mathrm{m}^{3}$ applied in two rounds of $0.25 \mathrm{~g} / \mathrm{m}^{3}$ resulted in high snail mortality and low lethality to fish, frogs, and tadpoles. Further studies are needed to assess the cost-effectiveness of Bayluscide in the control of schistosomiasis following the simplified approach.

Key words: schistosomiasis - water contact - molluscicide - integrated approach - Cameroon

Schistosomiasis is a parasitic disease affecting 200 millions people in tropical and subtropical countries. It is responsible for 754 million disability adjusted life years among children in Africa (WHO 2002). Its prevalence is rapidly increasing with the extension of water development projects (Hunter et al. 1996). Snail host control measures are best considered as part of an integrated approach in schistosomiasis morbidity control activities, dominated by population-based chemotherapy (Ripert 2003, Clennon et al. 2004). Molluscicides have been used to control schistosomiasis since the 1950 s, but this strategy has been criticized for its high cost and the damage that molluscicides cause to non-target organisms. Bayluscide, the most used synthetic molluscicide is effective against all developmental stages of snails and schistosomes (Tchounwou et al. 1991, 1992, Abu-Elyazeed et al. 1993, Lowe et al. 2005). At molluscicidal concentrations, Bayluscide is lethal to fish unless they can escape to unaffected parts of waterbodies (Evans 1983, Goll et al. 1984). Focal mollusciciding is a cost effective method for schistosomiasis control, particularly in arid regions where transmission sites are small and seasonal (Klumpp \& Chu 1987, Sarquis et al. 1997). Bayluscide application following the simplified technique (Greer et al. 1996) is effective at $0.5 \mathrm{~g} / \mathrm{m}^{3}$, half the recommended dose. The advantage of the simplified technique resides in the fact that heavier doses of the concentrate are applied to the margins of the water bodies where most snail hosts are found. Unfortunately, the death and putrefaction of non-target aquatic organisms such as fish, tadpoles, frogs, and earth worms

Financial support: WHO/TDR/IFORD

+Correspondind author: itakougang@yahoo.com

Received 12 September 2005

Accepted 15 May 2006 reduce the acceptability of molluscicide application. The present study was designed to field test whether a lower dose $\left(0.25 \mathrm{~g} / \mathrm{m}^{3}\right)$ of Bayluscide would kill fewer nontarget organisms, while maintaining its effect on snail host.

\section{MATERIALS AND METHODS}

The present investigations were carried out in the locality of Lara in the Mayo Kani Division of the sudanosahelian zone of Cameroon from July to October 1998. This study site was selected for its high prevalence of urinary schistosomiasis, its focal transmission in temporary habitats which are ideal conditions for mollusciciding. During a preliminary visit, health, administrative and village authorities were contacted and explained the goal of the project. Community consent was obtained from the traditional authorities. Ethical clearance was obtained from the Ministry of Health and the Ethical Committee of the Faculty of Medicine \& Biomedical Sciences. All study procedures followed were in accordance with the the Helsinki Declaration of 1975, as revised in 1983.

In order to assess the effect of Bayluscide on snail populations, water contact sites were identified, test and control ponds randomly assigned. Niclosamide or Bayluscide wettable powder $70 \%$ active ingredient (a.i.) was applied to study ponds at concentrations of $0,0.25,0.5$, and $1 \mathrm{~g} / \mathrm{m}^{3}$, following the simplified technique. The weight of niclosamide required for each application was derived from estimates of pool volumes assuming that the contours of pools approximated a segment of a sphere. The volume of water in each pond was determined based on a paced measurement of circumference from a standard scale developed earlier (Greer et al. 1996).

The dose of niclosamide was divided into four parts and one part applied to the margin of each of the pond quadrants. Ponds that were treated with 0.25 or $0.5 \mathrm{~g} / \mathrm{m}^{3}$ were retreated if live snails were found $24 \mathrm{~h}$ after Bayluscide application. Scoops made with a large kitchen strainer mounted on an iron support and attached to a 
broomstick were used for sampling snails. Ten scoops were sampled from each of the pond quadrants to assess snail population before treatment, $24 \mathrm{~h}, 28$ days and 56 days post treatment. Snails were determined to be alive or dead, separated by species and counted (Brown 1994). All ponds that were treated with 0 or $0.25 \mathrm{ppm}$ that harboured snail hosts $24 \mathrm{~h}$ post application were treated with Bayluscide at $0.5 \mathrm{ppm}$. The efficacy of Bayluscide on snail population was assessed by computing the average number of live snail count in standard 40 dip scoops for each of the test Bayluscide concentrations (Hairston 1965).

Investigation of fish, frogs, and tadpole kill was adapted from standard guidelines (APHA 1985). The kill was determined based on the numer of dead tadpole, fish or frog per 2000 adjusted paces of the pond circumference as nil (0), minor (1-100 dead), moderate (101-1000 dead) or major (> 1000 dead).

\section{RESULTS}

Before Bayluscide applications, all study ponds harboured Bulinus globosus and B. senegalensis, snail hosts of schistosome. However B. globosus was the main host. Two other freshwater snails were found, Lanistes ovum in two ponds and Ferrissia sp. in one pond.

The concentration of $0.5 \mathrm{ppm}$ worked just as well as the $1 \mathrm{ppm}(\mathrm{p}>0.10)$. The concentration of $0.25 \mathrm{ppm}$ was less effective than either 0.50 or $1 \mathrm{ppm}$ (Table I).

Bayluscide was applied to 16 ponds at concentrations of 0 ( 4 ponds), 0.25 ( 5 ponds), 0.5 (4 ponds), and $1 \mathrm{~g} / \mathrm{m}^{3}$ (3 ponds). All $0.25,0.5$, and $1 \mathrm{~g} / \mathrm{m}^{3}$ Bayluscide concentrations reduced snail population significantly. The decrease in snail count was $100 \%$ only in one case for the $0.25 \mathrm{ppm}$ concentration (Table II).

The degree of fish, frogs, and tadpoles kill was mini$\mathrm{mal}$ at $0.25 \mathrm{ppm}$ and increased with Bayluscide concentration (Table III). During a spot visit $24 \mathrm{~h}$ post application at one of the pond (\#4) which was treated with 0.50 ppm Bayluscide, we found many life frogs.

No fish kill was observed $24 \mathrm{~h}$ after a fish pond (\#16) was treated with Bayluscide at $0.5 \mathrm{ppm}$, in two rounds of $0.25 \mathrm{ppm}$. The reduction in snail population was significant one month (80\%) and two months (97\%) after treatment.

\section{DISCUSSION}

It is probable that the detection of live snails in some ponds after treatment with $0.25 \mathrm{ppm}$ could have been due to underdosing. The Bayluscide scale used was based on the assumption that all ponds in the region have similar shapes. In fact, some of the pools were rather deep, leading to underdosing. Nonetheless, the application of Bayluscide at $0.25 \mathrm{ppm}$ in such ponds led to a significant reduction in snail population.

The low fish kill observed at $0.25 \mathrm{ppm}$ in the Lara fish pond and the significant reduction in snail population confirms the efficacy of the simplified procedure. This is a major achievement of the present study. Human populations living in endemic areas have generally been resentful of molluscicides because they are lethal to fish stock. The fact that $0.50 \mathrm{ppm}$ applied in two rounds of $0.25 \mathrm{ppm}$, following the simplified procedure (Greer et al. 1996) was lethal to snails, but not to fish, frogs, and tadpoles rekindles the issue of schistosomiasis control through mollusciciding. As the quantity of Bayluscide used per unit of pond margin is reduced, the cost of mollusciciding may be lowered, thus improving its acceptability and costeffectiveness in schistosomiasis control. The advantage of the simplified procedure is that the villagers can easily be trained on safety guidelines, to recognise transmission sites and apply Bayluscide at effective regimens (Greer et al. 1996).

The effect of Bayluscide on non-target water organisms depends on the motility of these organisms in water, but also on their sensitivity to Bayluscide (Harrison 1966, Gebremedhin et al. 1994). The rapid mortality of B. globosus and $B$. senegalensis snails is due to its acute toxicity. Frogs and fish are capable of rapidly moving to areas of low chemical concentration in deeper sections of the pond. Because snails are practically immotile, they remain in areas of higher concentrations of Bayluscide at ponds margins. This explains the higher mortality in snails and increased survival of fish and frogs that are a valuable source of protein for the human population. The differential susceptibility of aquatic organisms to Bayluscide has been used elsewhere to control nuisance organisms in the aquaculture industry (Francis-Floyd et al. 1997). The live snail count registered at $24 \mathrm{~h}$ post application in some ponds may be related to the fact that this period is still within the $48 \mathrm{~h}$ recovery period reported earlier for Biomphalaria stramina in Brazil (Giovanelli et al. 2002). Earlier reports of snail escape behaviour including water leaving and burrowing (Sarquis et al. 1997) were not investigated, but with the relatively heavy concentration of Bayluscide that were applied on pond margins, it is not feasible that any affected snail could have escaped. In the present study, the assessment of fish, frogs, and tadpole kill was limited by the fact that not all ponds harboured these organisms. It would have been usefull to determine pre application estimation of non-target organism population, as the impact assessment would have then been stronger. Whereas this limitation may decrease the strength of our assertions, it does not decrease the validity of our observations. We used our observational evidence to determine the presence of these organisms, and believe these to be sufficient for our estimations. As labour costs and the cost of Bayluscide represents more than $75 \%$ of molluscicide programmes (Evans 1983), the implementation of the simplified procedure by villagers (Greer et al.

\section{TABLE I}

Comparison of the efficacy of various concentrations of Bayluscide on Bulinus globosus snail host

\begin{tabular}{lcccc}
\hline $\begin{array}{l}\text { Bayluscide } \\
\text { concentration }\end{array}$ & $0.0 \mathrm{ppm}$ & $0.25 \mathrm{ppm}$ & $0.5 \mathrm{ppm}$ & $1 \mathrm{ppm}$ \\
\hline $0.00 \mathrm{ppm}$ & $\mathrm{NS}$ & $* * *$ & $* * *$ & $* * *$ \\
$0.25 \mathrm{ppm}$ & & $\mathrm{NS}$ & $\mathrm{NS}$ & $* * *$ \\
$0.50 \mathrm{ppm}$ & & & $\mathrm{NS}$ & $* * *$ \\
$1 \mathrm{ppm}$ & & & & $\mathrm{NS}$ \\
\hline
\end{tabular}

NS: non significant difference; $* * *$ : higly significant diference $(\mathrm{p}<0.001)$. 
$$
\text { . }
$$

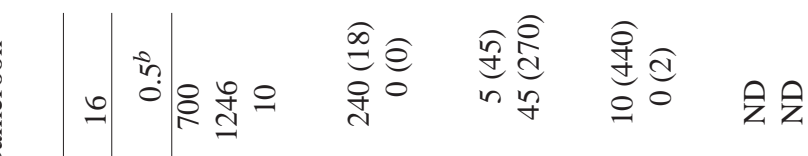

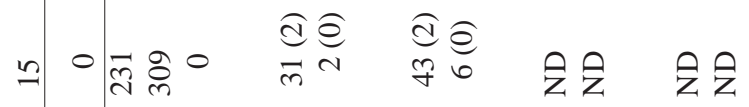

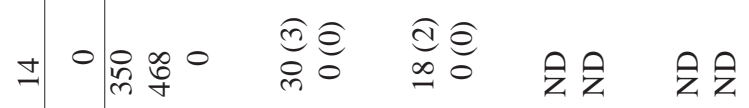

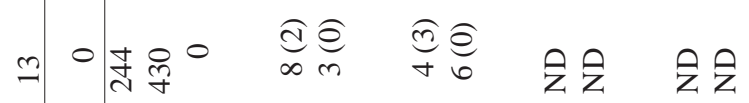

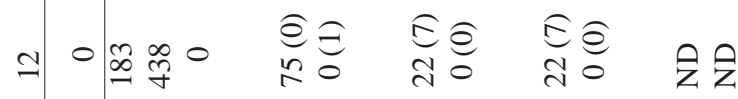
$=$ =

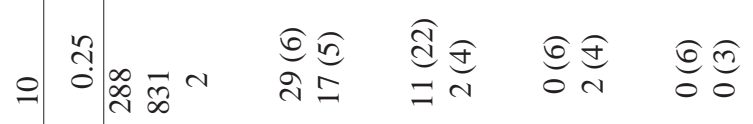

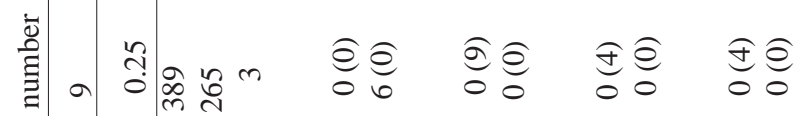

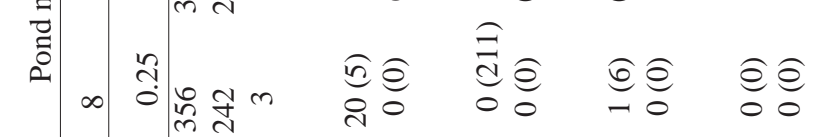
业

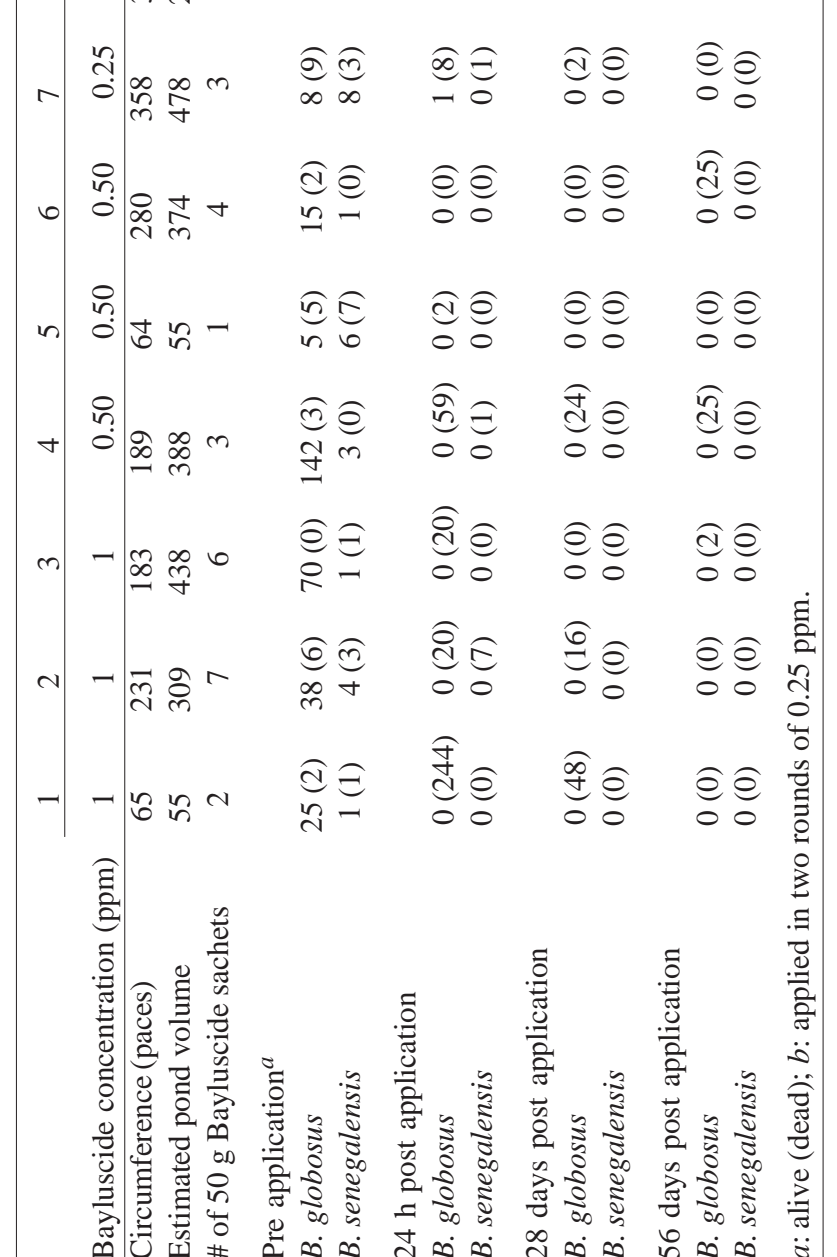

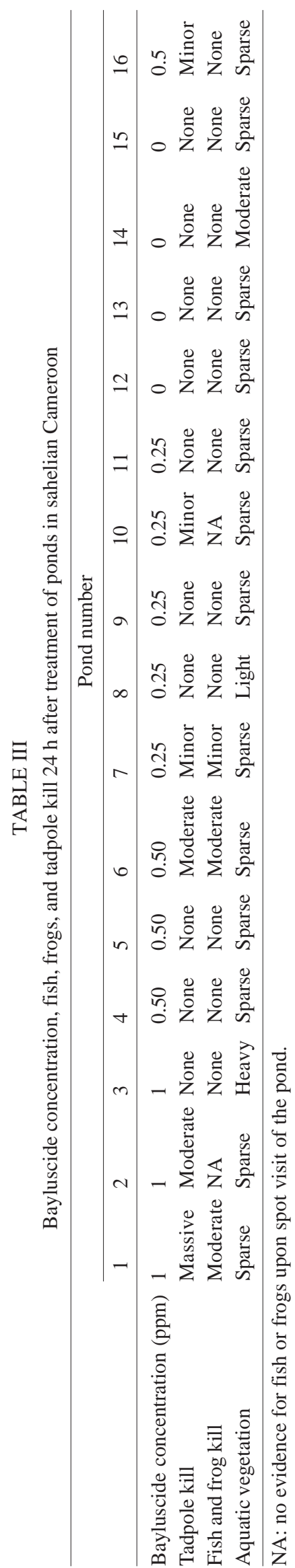


1996), the reduced efficacious quantity of Bayluscide used per pond, mollusciding should have a greater cost-effectiveness and acceptability. Mollusciding has been reported to be a cost-effective community intervention strategy against schistosomiasis in temporary transmission foci, in conditions where water contact is intense and the prevalence among school children is over 50\% (Pieri 1995). Such is the case in the sahelian zone of Cameroon which harbors over $85 \%$ of schistosomiasis cases where the transmission foci are relatively small seasonal waterbodies (Ratard et al. 1990, Greer et al. 1990). Unfortunatelly, because of earlier equivocal beliefs about mollusciciding, studies and interventions on snail control have been underrated (Sarquis et al. 1997). With the reduced quantity of effective molluscicide using the regimen described in the present study, futher studies should be carried to assess the cost-efficiency and sustainability of Bayluscide application for the control of schistosomiasis in cojunction with other community based treatment methods (Chippaux $\&$ Massougbodji 2004). Bayluscide should be applied following the simplified procedure in two round of $0.25 \mathrm{ppm}$, so as to maintain its efficacy on snail hosts while reducing its effect on non target freshwater fish, frogs, and tadpoles. The simplified procedure may apply in areas where transmission is focal. It will also be effective in lentic habitats where most of the snail population is located on water body margins. This would be the case for lakes or dams. This approach is simple and could facilitate the integration mollusciciding for schistosomiasis control in the primary health care package.

\section{ACKNOWLEDGEMENTS}

To the people of Lara, whose collaboration and understanding was crucial to the execution of the present study; to Professors Moses F Asanji and Norbert Ndong for their collaboration which was indispensable for the execution of this work.

\section{REFERENCES}

Abu-Elyazeed RR, Podgore JK, Mansour NS, Kilpatrick ME 1993. Field trial of $1 \%$ niclosamide as a topical antipenetrant to Schistosoma mansoni cercariae. Am J Trop Med Hyg 49: 403-409.

APHA 1985. Investigation of fish kills. In MAH Franson, Standard Methods for the Examination of Water and Wastewater, 16th ed., Washington.

Brown D 1994. Freshwater Snails of Africa and Their Medical Importance, 2nd ed., Taylor \& Francis, London.

Chippaux J-P, Massougbodji A. 2004. Synthèse et recommendations de la table ronde "Contrôle des schistosomoses en Afrique sub-saharienne". Bull Soc Pathol Exot 97: 3-5.

Clennon JA, King CH, Muchiri EM, Kariuki HC, Ouma JH, Mungai P, Kitron U 2004. Spatial patterns of urinary schistosomiasis infection in a highly endemic area of costal Kenya. Am J Trop Med Hyg 70: 443-448.

Evans AC 1983. Control of schistosomiasis in large irrigation schemes bus use of niclosamide. A ten years study in Zimbabwe. Am J Trop Med Hyg 32: 1029-1039.

Francis-Floyd RJ, Gildea J, Reed P, Klinger R 1997. Use of Bayluscide (Bayer 73) for snail control in fish ponds. $J$ Aquatic Animal Health 9: 41-48.
Gebredhin G, Adewumi CO, Becker W, Agbedahunsi JM, Dorfler G 1994. Hirudicinal activities of some natural molluscicides used in schistosomiasis control. J Ethnopharmacol 41: 127-132.

Giovanelli A, Coelho da Silva PA, Medeiros L, Carvalho de Vasconcellos MC 2002. The molluscicidal activity of Niclosamide (Bayluscide WP 70) on Melanoides tuberculata (Thiaridae), a snail associated with habitats of Biomphalaria glabrata (Planorbidae). Mem Inst Oswaldo Cruz 97: 743745 .

Gool PH, Wilkins HA, De Marshall TF 1984. Dynamics of Schistosoma haematobium infection in a Gambian Community. II. The effect on transmission of the control of Bulinus senegalensis by the use of niclosamide. Tran R Soc Trop Med Hyg 78: 222-226.

Greer GJ, Mimpfoundi R, Malek EA, Joky A, Ngonseu E, Ratard C 1990. Human schistosomiasis in Cameroon. II. Distribution of the snail hosts. Am J Trop Med Hyg 42: 573-580.

Greer GJ, Tchounwou PB, Takougang I, Monkiedje A 1996. Field test of a village-based mollusciciding programme for the control of snail hosts of human schistosomes in Cameroon. Trop Med Int Hlth 1: 320-327.

Hairston NG 1965. Statistical analysis of molluscicide field trials. Bull WHO 32: 289-296.

Harrison AD 1966. The effects of Bayluscide on Gastropod snails and other aquatic fauna. Hydrobiologia 28: 371-384.

Hunter JM, Rey L, Chu Y, Adekolu-John EO, Mott KE 1996. Parasitic Diseases in Water Resources Development: the Need for Intersectorial Negociation, WHO, Geneva.

Klump RK, Chu KY 1987. Focal mollusciciding: an effective way to augment chemotherapy of schistosomiasis. Parasitol Today 3: 74-76.

Lowe D, Xi J, Meng X, Wu Z, Qiu D, Spear R 2005. Transport of Schistosoma japonicum cercariae and the feasibility of niclosamine for cercariae control. Parasitol Int 54: 83-89.

Pieri OS 1995. Perspectivas no controle ambiental dos moluscos vetores da esquimossomose. In Tópicos em Malacologia Médica, Fiocruz, Rio de Janeiro, p. 237-252.

Ratard RC, Kouemeni LE, Ekani M-M, Ndamkou CN, Greer GJ, Spilsbury J, Cline BL 1990. Human schistosomiasis in Cameroon. I. Distribution of schistosomiasis. Am J Trop Med Hyg 42: 561-572.

Ripert C 2003. Schistosomose due à Schistosoma intercalatum et urbanisation en Afrique Centrale. Bull Soc Path Exot 96: 183-186.

Sarquis O, Pieri O, dos Santos JA 1997. Effects of Bayluscide WP 70 on the survival and water leaving behaviour of Biomphalaria straminea, snail host of schistosomiasis in Northeast Brazil. Mem Inst Oswaldo Cruz 92: 619-623.

Tchounwou PB, Englande Jr AJ, Malek EA 1991. Toxicity evaluation of Bayluscide and malathion to three developmentatl stages of freshwater snails. Arch Environ Contam Toxicol 21:351-358.

Tchounwou PB, Englande Jr AJ, Malek EA 1992. The influence of selected environmental parameters on the toxicity of Bayluscide to Schistosoma mansoni miracidia. Arch Environ Contam Toxicol 23: 223-229.

WHO-World Health Organization 2002. Rapport sur la santé dans le monde, Geneve. 